\title{
Partial Purification and Characterisation of Sulphur Oxidase from Micrococcus sp. and Klebsiella sp. Isolated from Mangrove Soils of Mahanadi River Delta, Odisha, India
}

\author{
B. C. Behera ${ }^{1}$, S. K. Singh ${ }^{2}$, M. Patra ${ }^{3}$, R. R. Mishra ${ }^{3}$, B. K.Sethi ${ }^{3}$, S. K. Dutta ${ }^{4}$ H. N. Thatoi ${ }^{1, *}$ \\ ${ }^{1}$ Department of Biotechnology, North Orissa University, India \\ ${ }^{2}$ Department of Biotechnology, Pondicherry Central University, India \\ ${ }^{3}$ Department of Biotechnology, MITS School of Biotechnology, India \\ ${ }^{4}$ Department of Zoology, North Orissa University, India
}

Copyright $\mathrm{O} 2016$ by authors, all rights reserved. Authors agree that this article remains permanently open access under the terms of the Creative Commons Attribution License 4.0 International License

\begin{abstract}
As knowledge of sulphur oxidising bacterial communities in mangrove sediments is very sparse and sulphur oxidizers have wide application such as in treatment of wastewater containing high sulphate levels which causes unwanted $\mathrm{H}_{2} \mathrm{~S}$ production by sulfate reducing bacteria (SRB), oxidation of elemental sulphur to plant available sulphate for plant growth promotion, bio leaching, biocontroling agent etc. Hence, in the present study an attempt has been made to explore the diversity of sulphur oxidizing bacteria from mangroves of Mahanadi delta, Odisha to evaluate their biotechnological potential. Two sulphur oxidising bacteria (SOB-7and SOB-8) were isolated from mangrove soils of Mahanadi river delta, based on the change of colour of the thiosulphate broth medium from purple to colour less by reducing the $\mathrm{pH}$. Based on morphological, biochemical and 16S rRNA gene sequencing the two strains (SOB-7) and (SOB-8) were identified as Klebsiella sp., and Micrococcus sp. respectively. The gene bank accession number of the strains are KR632644 (SOB-7) and KR632643 (SOB-8). The strain Klebsiella sp. and Micrococcus sp showed sulphate ion production ability of $243 \mathrm{mg} / \mathrm{ml}$ and $240 \mathrm{mg} / \mathrm{ml}$ respectively with decrease in $\mathrm{pH}$ from 7.0 to 4.0. Among these two isolates, SOB-8 showed higher sulphide oxidase production ability $(126.83 \mathrm{U} / \mathrm{ml})$ than the isolate, SOB-7 $(126.0 \mathrm{U} / \mathrm{ml})$. Maximum sulphide oxidase by both the strains were obtained at temperature $45^{\circ} \mathrm{C}$, peptone as nitrogen source, thiosulphate concentration of $10 \mathrm{mg} / \mathrm{ml}$. pH 9.0 for the isolate SOB- 8 whereas $\mathrm{pH} 7.0$ for the isolate, SOB-7. Partially purified enzyme of both the isolate showed higher activity at same substrate concentration of $1.5 \mathrm{mg} / \mathrm{ml}$, but varies with $\mathrm{pH}$ and temperature.
\end{abstract}

Keywords Bromophenol Blue, Mangrove Ecosystem, Sodium Thiosulphate, Sulphur Oxidase, Sulphate Ion

\section{Introduction}

Sulphur is the fourth major plant nutrient after N, P and K, and is one of the sixteen nutrient elements which are essential for the growth and development of plants, especially in the agricultural crop production [1]. Sulphur is required because of its structural role in the amino acids cysteine and methionine and it is present in number of vitamins, such as thiamine, biotin and lipoic acid, as well as in coenzyme A [2]. The majority of sulphur taken up by plant roots is in the form of sulphate $\left(\mathrm{SO}_{4}\right)$, which undergoes a series of transformations prior to its incorporation into the original compounds [3]. The soil microbial biomass is the key driving force behind all sulphur transformation. Biological oxidation of hydrogen sulphide to sulphate is one of the major challenges of the global sulphur cycle [4]. Sulphur oxidizing bacteria present in soil oxidize various sulphur compounds and improve soil fertility. It results in the formation of sulphate, which can be used by plants, while the acidity produced by oxidation helps to solubilise plant nutrients [5]. Sulphide oxidase is the key enzyme produced by these microorganisms, responsible for sulphide ions oxidation [6].

Beside their important contribution in agriculture sulphur oxidising bacteria also play significant role in removal of toxic $\mathrm{H}_{2} \mathrm{~S}$ from the environment. Sulfur containing volatile compounds such as hydrogen sulphide, methanol, dimethyl sulphide and dimethyl disulfide, which are major malodorous components generated from domestic animal waste, sewage treatment facilities and chemical factories. Sulphur oxidizing microorganisms have the ability to 
deodorize these malodorous sulphur components. [7].

Mangrove ecosystem is characterized by periodic tidal flooding which makes environmental factors such as salinity and nutrient availability highly variable, resulting in unique and specific characteristics [8]. These are tropical coastal biome, located in the transition zone between land and sea, where the vegetation is dominated by a particular group of plant species [9]. Mangrove soils are sulphidic and variable, since their chemistry is regulated by a variety of factors such as texture, tidal range and elevation, redox state, bioturbation intensity, forest type, temperature and rainfall [10]. Bacteria are the major participants in the biogeo-chemical cycles in mangrove forest [11]. In this anoxic mud of marine estuaries and coastal sediments the anaerobic, heterotrophic metabolism of sulfate-reducing bacteria is responsible for most of the production of hydrogen sulfide $\left(\mathrm{H}_{2} \mathrm{~S}\right)$. Sulphate reducing bacteria use sulphate as a terminal electron acceptor for the degradation of organic compounds, resulting in the production of sulphide. Subsequently, the sulphide can be oxidized by sulphur oxidising bacteria to produce sulphate. [12]. As the original source of reduced sulfur compounds, $\mathrm{H}_{2} \mathrm{~S}$ hence, supports abundant populations of sulfur-oxidizing bacteria at the oxic-anoxic interface [13]. A phylogenetic and functional description of sulphur oxidising bacterial diversity in the mangrove ecosystem has not been addressed to the same extent as that of other environments [14]. To date, only a few obligately heterotrophic bacteria have been studied in detail and adequately described that are able to generate metabolically useful energy from the oxidation of reduced sulfur compounds. A more thorough description of the sulphur oxidising bacterial diversity and distribution in a mangrove would improve our understanding of sulphur geochemistry as well as microbial metabolism of suphur in that ecosystem. Keeping the above in vision the present investigation is aimed to isolate, characterize and estimate the sulphur oxidising ability of sulphur oxidizing bacteria from mangrove soil of Mahanadi river delta, Odisha, India.

\section{Materials and Methods}

\subsection{Isolation of Sulphur Oxidising Bacteria}

The mangrove area in the Mahanadi delta $\left(20^{\circ} 15^{\prime \prime}\right.$ to $20^{\circ}$ $70^{\prime} \mathrm{N}$ latitude and $87^{\circ}$ to $87^{\circ} 40^{\prime} \mathrm{E}$ longitude) extends from south eastern boundary of Mahanadi river to river mouth of Hansua (a tributary of Brahmani) in the north, from the north eastern end of Mahanadi river up to Jamboo river in east. The soil samples were collected from different location of mangrove forest such as Jumbo, Kharnasi, Triveni, Nuagada, Atharabanki and Mangrove forest at Indian Farmer fertilizers Corporation (IFFCO). Top layer of soil (about $1 \mathrm{~cm}$ ) was removed. In each site soil samples were collected from five different spots. Samples were mixed thoroughly and put in sterile polythene bags with proper labeling, stored in ice box and brought to the laboratory for further analysis. In the laboratory, the samples were stored at $4 \pm 0.1^{\circ} \mathrm{C}$ in a refrigerator. For each soil sample, several sub-samples were taken, homogenized in sterile Milliq water containing $0.85 \%$ $\mathrm{NaCl}(\mathrm{w} / \mathrm{v})$ and serially diluted and poured on sulphur oxidising agar plate medium containing [15] $10 \mathrm{~g}$ of bacto-peptone, $1.5 \mathrm{~g}$ of $\mathrm{K}_{2} \mathrm{HPO}_{4}, 0.75 \mathrm{~g}$ of ferric ammonium citrate and $1.0 \mathrm{~g}$ of $\mathrm{Na}_{2} \mathrm{~S}_{2} \mathrm{O}_{3} .5 \mathrm{H}_{2} \mathrm{O}$ and agar $15 \mathrm{~g}$ per liter. The initial $\mathrm{pH}$ was adjusted to 7.0 using $1 \mathrm{M} \mathrm{HCl}$ before sterilizing by autoclave. The plates were incubated at $30{ }^{\circ} \mathrm{C}$ for $24 \mathrm{~h}$. The morphologically distinct isolated colonies appeared on the plate were picked up by wire loop and re-streaked on the other sulphur-oxidizer medium agar plate for purity conformation. For qualitative screening of distinct sulphur oxidising bacteria, the isolated bacteria were further grown on the thiosulphate broth [16] containing: $5.0 \mathrm{~g}$ $\mathrm{Na}_{2} \mathrm{~S}_{2} \mathrm{O}_{3}, 0.1 \mathrm{~g} \mathrm{~K}_{2} \mathrm{HPO}_{4}, 0.2 \mathrm{~g} \mathrm{NaHCO}_{3}$ and $0.1 \mathrm{~g} \mathrm{NH}_{4} \mathrm{Cl}$ in $1000 \mathrm{ml}$ distilled water, with $\mathrm{pH}$ 8.0. Bromophenol blue was used as the indicator. The cultures which changed the colour of the thiosulphate broth from purple to colour less by reducing the $\mathrm{pH}$ after incubation for 3 days at $30^{\circ} \mathrm{C}$ were selected for further characterisation and evaluation of their sulphate ion and sulphide oxidase activity.

\subsection{Identification of the Bacterial Strain}

Culture characteristics such as colony appearance, spore formation, and motility of each strain were tested according to the standard methods. Morphology of the bacterial isolates was checked with scanning electron microscope (Zeiss, Sigma). We also tested for catalase and urease production, indole production, nitrate reduction, citrate utilization, and acid-gas production from sugar. In addition, we tested for acetyl methyl carbinol production by the Voges-Proskauer (V-P) reaction. Hydrolysis of tributyrin, Tween-80, cholesterol, gelatin, casein, pectin and chitin by the culture was also determined. The results were compared with Bergey's Manual of Determinative Bacteriology [17].

$16 \mathrm{~S}$ rRNA gene of two most efficient isolates were amplified using universal 27F forward primer (5' AGGCCTAACACATGCAAGTC-3') and 1492R reverse primer (5'GGGCGGWGTGTACAAGGGC- 3') described by Das et al. [18]. A PCR product of 16S rRNA (1500bp) was purified using QIA quick gel extraction kit, QIAGEN, $\mathrm{GmbH}$ (Germany) and nucleotide sequence were determined using the big dye terminator $\mathrm{v} 3.1$ cycle sequencing kit in an automated 3130xl genetic analyzer system (Applied Biosystems, HITACHI, USA) and submitted to gene bank. The resultant sequences were aligned using Seqscape software (Applied Biosystems, USA) to get full length sequence. The BLAST programs of the National Centre for Biotechnology Information (http://www.ncbi.nlm.nhi.gov) were used to search databases for similar nucleotide and genus identification. A phylogenetic tree was constructed using MEGA 4.0 software using the neighbor joining DNA distance algorithm. 


\subsection{Sulphate Ion Determination}

The amount of sulphate ion $\left(\mathrm{SO}_{4}^{2-}\right)$ produced during growth of sulphur-oxidizing bacteria on thiosulphate broth medium was determined spectrophotometrically. Sulphate was measured by adding 1:1 barium chloride solution $(10 \%$ w/v) with supernatant mix vigorously [19]. A resulting, white turbidity due to barium sulphate formation was measured at $450 \mathrm{~nm}$ with spectrophotometer (Systronics 119). Potassium sulphate $\left(\mathrm{K}_{2} \mathrm{SO}_{4}\right)$ was used as standard to construct a sulphate calibration curve [20].

\subsection{Sulphide Oxidase Assay}

The sulphide oxidase activity was determined by measuring the product of enzymatic reaction, sulphate $\left(\mathrm{SO}_{4}{ }^{2-}\right)$ in the reaction mixture following the standard method of Hirano et al. [21]. The reaction was initiated by addition of $0.5 \mathrm{ml}$ of sodium sulphide $\left(\mathrm{Na}_{2} \mathrm{~S}\right)$ solution into the reaction mixture that contain $4.5 \mathrm{ml}$ of $0.1 \mathrm{M}$ sodium acetate buffer (pH 5.6) and $1 \mathrm{ml}$ crude enzyme supernatant. The $\mathrm{Na}_{2} \mathrm{~S}$ solution was prepared by dissolving $0.06 \mathrm{~g} \mathrm{Na}_{2} \mathrm{~S}$ in an alkaline solution consisting of $0.16 \mathrm{~g} \mathrm{NaOH}, 0.02 \mathrm{~g}$ EDTA $\mathrm{Na}_{2} \cdot 2 \mathrm{H}_{2} \mathrm{O}$ (sodium ethylene diamine tetra acetic acid), $2 \mathrm{ml}$ glycerol and $40 \mathrm{ml}$ distilled water. The $\mathrm{Na}_{2} \mathrm{~S}$ solution was freshly prepared prior to use. The mixture was incubated for 30 minutes at $30^{\circ} \mathrm{C}$ and the reaction was subsequently terminated by the addition of $1.5 \mathrm{ml} \mathrm{NaOH}(1.0 \mathrm{M})$ followed by thorough mixing. Concentration of sulphate ion formed during sulphide oxidase assay was detected by the reaction of equal volume of barium chloride solution $(10 \% \mathrm{w} / \mathrm{v})$ and reactant and the absorbance was measured at $450 \mathrm{~nm}$ using spectrophotometer. The measurement of sulphate ion in the sample was based upon the formation of barium sulphate after addition of barium chloride which leads to the white turbidity. The amount of turbidity formed is proportional to the sulphate ion concentration in the sample. One unit of sulphide oxidase activity was defined as amount of enzyme required to produce $1 \mu \mathrm{mol}$ sulphate per hour per $\mathrm{ml}(\mathrm{U} / \mathrm{ml})$.

\subsection{Optimisation of Growth Medium Parameters for the Production Of Sulphide Oxidase}

Optimisation of sulphide oxidase production was carried out by inoculating the bacterial culture in the growth medium with respect to different environmental conditions such as $\mathrm{pH}$, temperature, thiosulphate concentration and nitrogen source. Enzyme activities were measured following the standard method of Hirano et al. [21].

\subsection{Partial Purification of Sulphide Oxidase}

Partial purification of sulphide oxidase was carried out by ammonium sulphate precipitation followed by dialysis. The gradient ammonium sulphate precipitation $(70 \%)$ was carried out with chilled cell free culture broth. The precipitate was collected by centrifugation after two hours incubation at $4{ }^{\circ} \mathrm{C}$ and dissolved in $0.2 \mathrm{M}$ phosphate buffer
(pH 7.0). The enzyme extract was dialyzed overnight against the same buffer at $4^{\circ} \mathrm{C}$ and the dialyzed enzyme was used for further studies. To estimate the molecular weight of the partially purified enzyme, SDS-PAGE was done using 5\% stacking gel and $10 \%$ resolving gel according to the method of Laemmli [22] and electrophoresis was done with $15 \mathrm{~mA}$ fixed current. Quantification of protein content of crude and partially purified phosphatase was done following the method of Lowry et al. [23], with Bovine serum albumin as a standard (Sigma, Germany).

\subsection{Characterisation of Partially Purified Sulphide Oxidase}

For characterization, the partially purified enzymes were subjected to different parameters such as $\mathrm{pH}$, temperature and substrate concentration and sulphide oxidase activity was measured following the standard method of Hirano et al. [21].

\section{Results}

\subsection{Isolation of Sulphur Oxidizing Bacteria}

Two sulphur oxidising bacteria were isolated from mangrove soil sample of Mahanadi delta, Odisha using sulphur oxidizer-agar medium. Morphologically distinct bacterial isolates forming distinct colony on agar medium were isolated and inoculated on thiosulphate broth medium containing bromophenol blue (BPB) as an indicator. These bacterial isolates were able to change the colour of the BPB in thiosulphate broth medium by reducing the $\mathrm{pH}$ of the medium from initial $\mathrm{pH}$ 8.0. Both the isolates, SOB-7 (4.0) and SOB-8 (4.1) were found to decrease the $\mathrm{pH}$ of the medium more efficiently.

\subsection{Identification of the Bacterial Strain}

Based on morphological (Figure 1) and several biochemical test such as, gram stain, spore formation, motility, catalase, urease, indole, nitrate reduction, citrate utilization, acid-gas production, Voges-Proskauer (V-P) reaction, hydrolysis of tributyrin, tween-80, cholesterol, gelatin, casein, pectin and chitin, the bacterium, SOB-7 was tentatively assigned to the Klebsiella sp. and SOB-8 as Micrococcus sp. Further confirmation of genus was done by BLAST analysis data of the 16S rRNA gene sequence which showed similarity of SOB-7 with the genus Klebsiella sp. and SOB-8 as Micrococcus sp. Both sequences were submitted to gene bank. The gene bank accession number of the strain SOB-7 is KR632644 and SOB-8 is KR632643. Phylogenetic tree were constructed by comparing nucleotide sequences of 16S rRNA gene of the isolate, SOB-7 with different Klebsiella sp. and of the isolate, SOB-8 with different Micrococcus sp. We found that the isolate SOB-7 is most closely related to Klebsiella sp. (Figure 2) and SOB-8 related to Micrococcus sp. (Figure 3). 

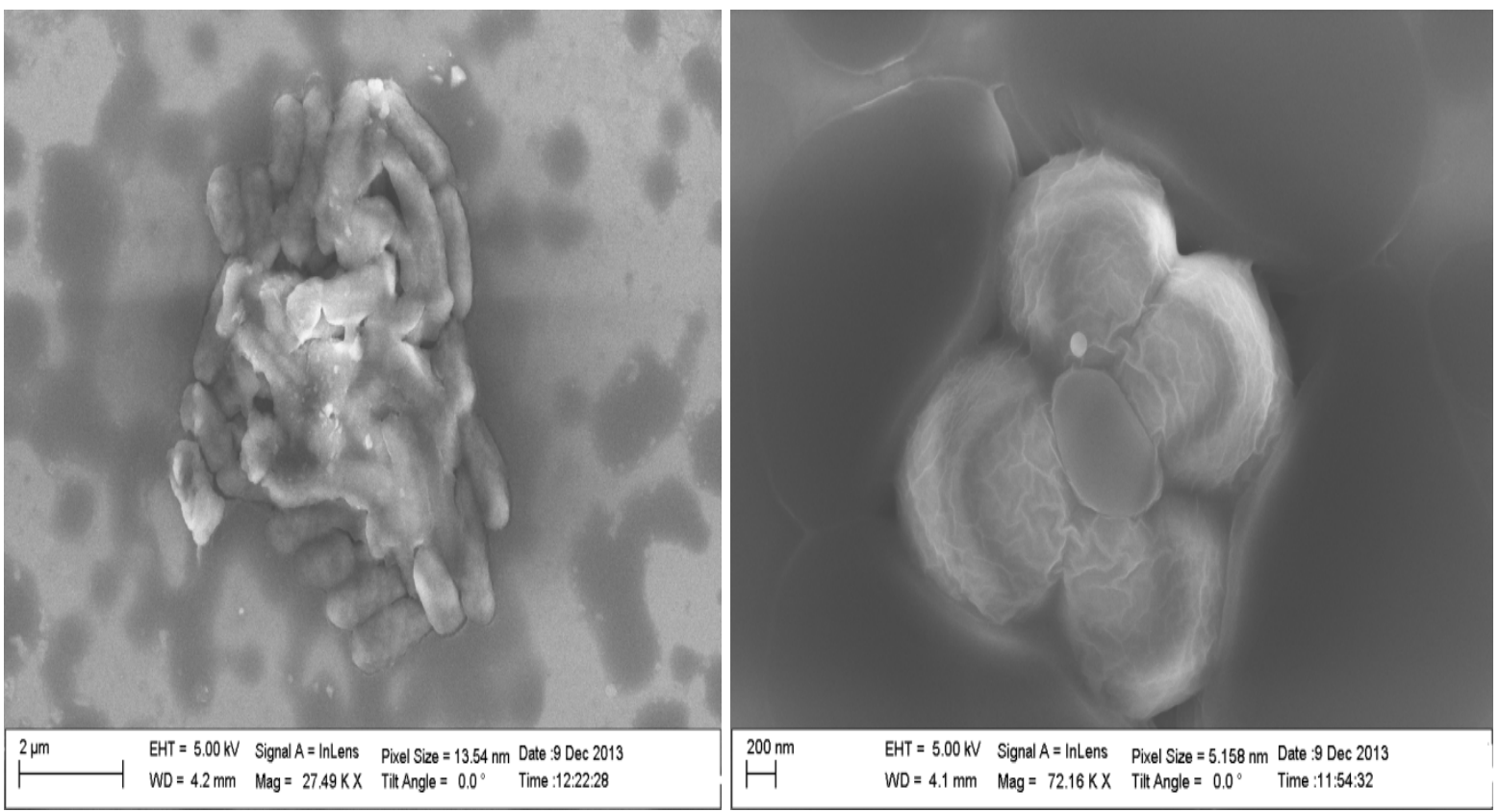

Figure 1. SEM photograph of (left) Klebsiella Sp. and (right) Micrococcus sp.

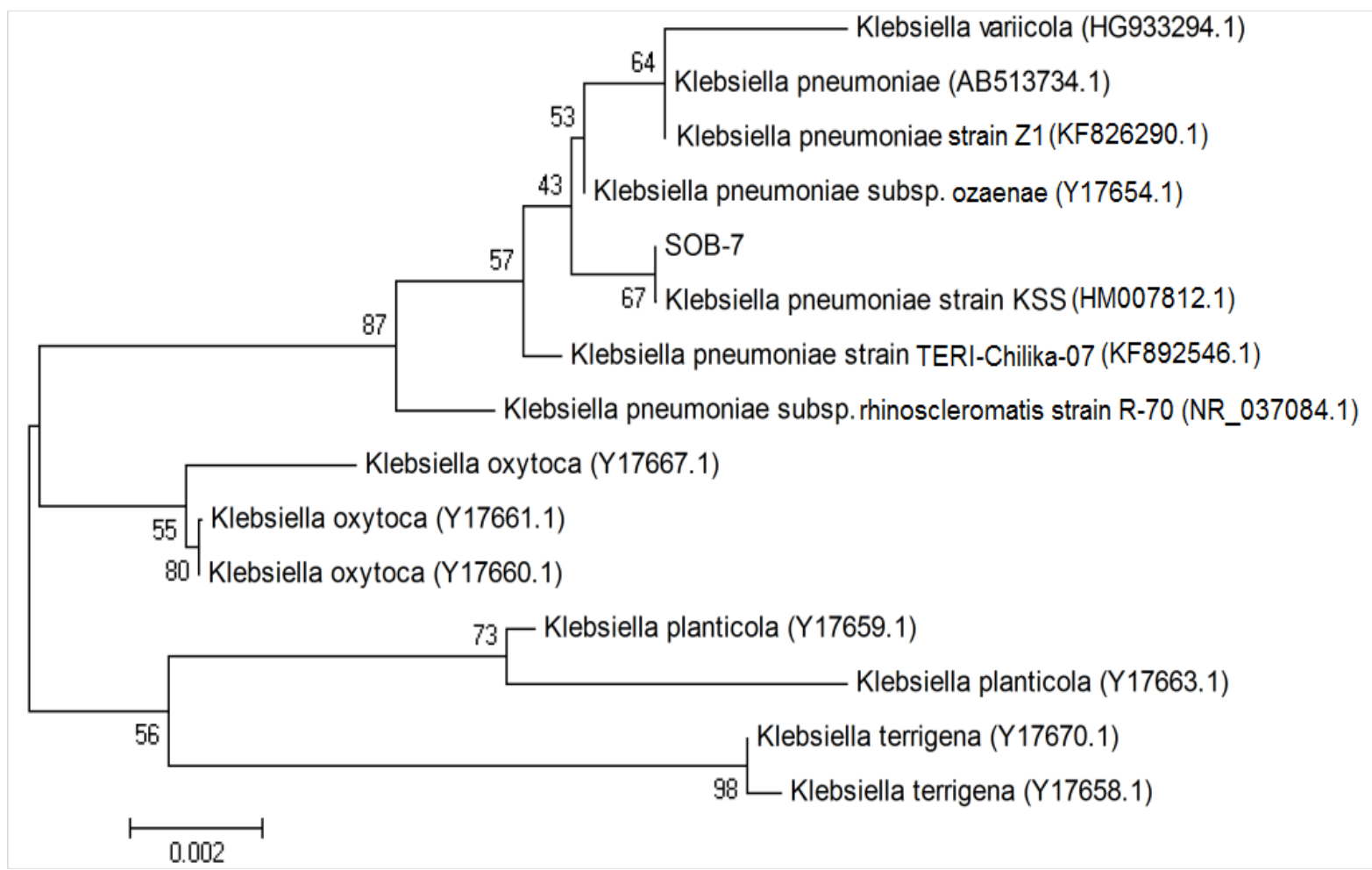

Figure 2. Phylogenetic tree of Klebsiella sp. (SOB-7) isolated from mangrove soil of Mahanadi river delta. 


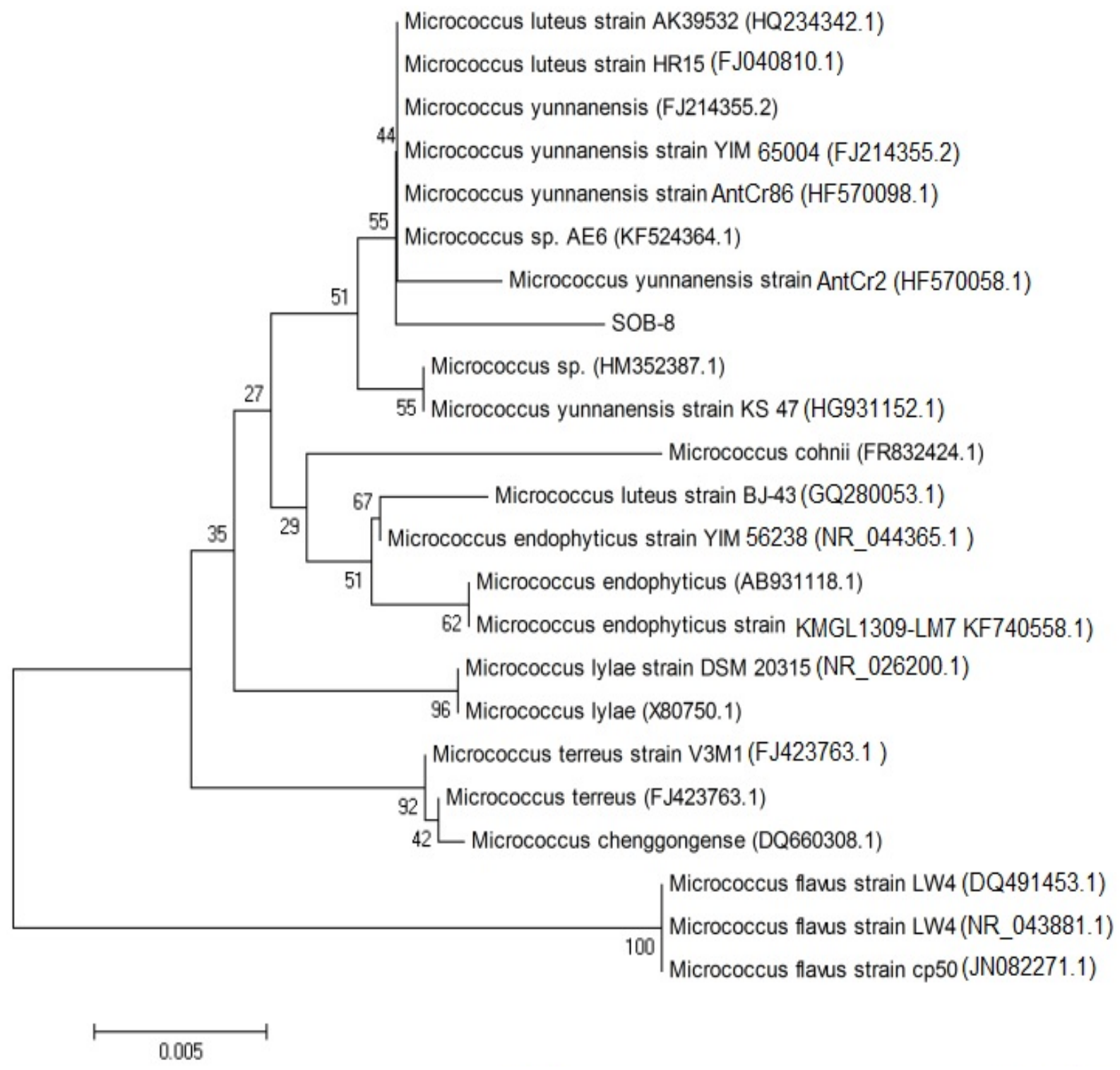

Figure 3. Phylogenetic tree of Microccus sp. (SOB-8) isolated from mangrove soil of Mahanadi river delta

\subsection{Sulphate Ion Determination}

The amount of sulphate ion produced and changes in $\mathrm{pH}$ taken place in the medium up to $264 \mathrm{~h}$ of incubation are presented. Productions of sulphate ion in the liquid medium by both the strains were accompanied by significant drop in $\mathrm{pH}$ values from an initial $\mathrm{pH}$ of 8.0. In the control no sulphate ion was detected as well no drop in $\mathrm{pH}$ was observed. However among the two bacterial isolates, the maximum sulphate ion production was observed by the bacterial isolate, SOB-7 $(245 \mathrm{mg} / \mathrm{ml})$ with maximum decrease in $\mathrm{pH}(\mathrm{pH} \mathrm{4.0)}$ of the medium (Figure 4) followed by the bacterial isolate, SOB-8 (240 mg/ml) with decrease in $\mathrm{pH}$ value of 4.1 of the thiosulphate broth medium (Figure 5). 


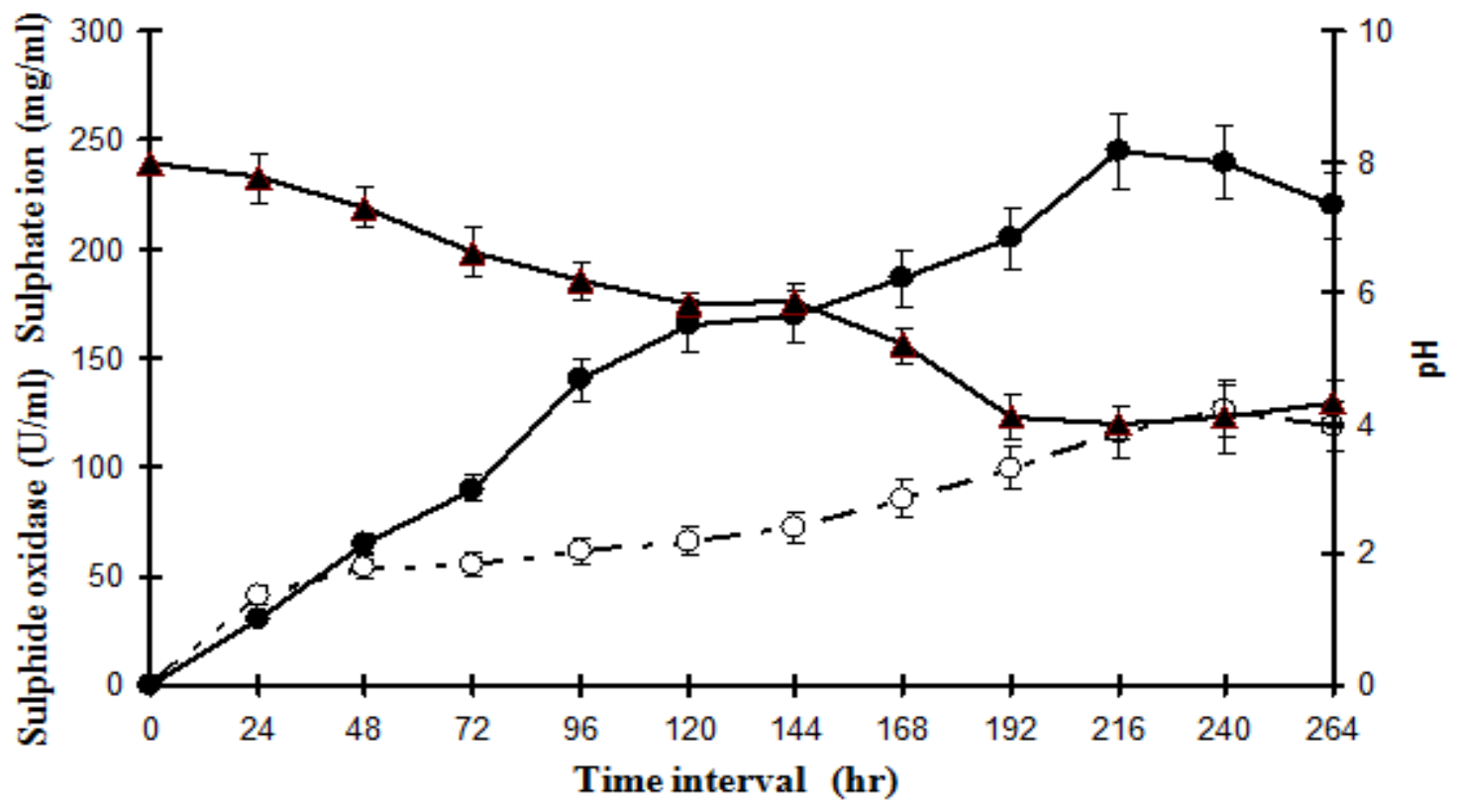

-め - Sulphide oxidase $\mathrm{U} / \mathrm{ml} / \mathrm{min} \longrightarrow$-Sulphate ion $\mathrm{mg} / \mathrm{ml} \longrightarrow \mathrm{pH}$

Figure 4. Comparative $\mathrm{pH}$ reduction, sulphate ion production and sulphide oxidase production ability of Klebsiella sp.

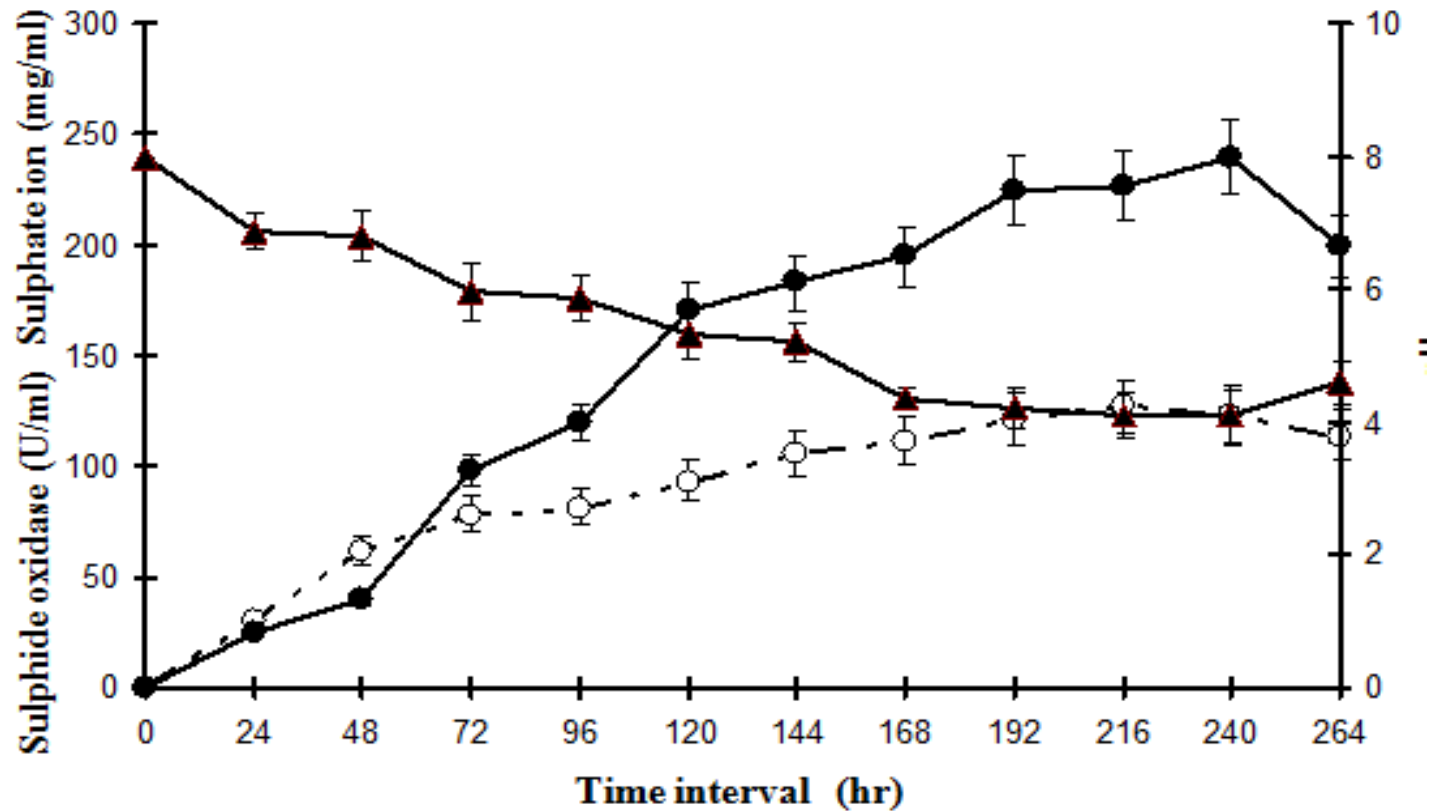

- - Sulphide oxidase $\mathrm{U} / \mathrm{ml} / \mathrm{min} \longrightarrow$ Sulphate ion $\mathrm{mg} / \mathrm{ml} \longrightarrow$ - $\longrightarrow$

Figure 5. Comparative pH reduction, sulphate ion production and sulphide oxidase production ability of Micrococcus sp.

\subsection{Sulphide Oxidase Assay}

Experiments were carried out to determine the sulphide oxidase production ability (S.O. activity) of two bacterial isolates (SOB-7 and SOB-8) during 264 hours of incubation. Among these two isolates, SOB-8 showed higher sulphide oxidase production activity $(126.83 \mathrm{U} / \mathrm{ml})$ than the isolate, SOB-7 $(126 \mathrm{U} / \mathrm{ml})$.

\subsection{Optimization of Growth Condition for Sulphide Oxidase Production}

Optimization of growth condition for sulphide oxidase production was carried out by maintaining the culture medium at different $\mathrm{pH}$, temperature, nitrogen sources and thiosulphate concentration. Effect of $\mathrm{pH}$ on enzyme production showed that very less sulphide oxidase produced 
by both the isolates when the initial $\mathrm{pH}$ of the culture medium was maintained at $\mathrm{pH} 3.0$ (Figure 6a). Maximum sulphide oxidase production $(123.66 \mathrm{U} / \mathrm{ml})$ was observed by the isolate SOB-7 when the initial $\mathrm{pH}$ of the culture medium was maintained at $\mathrm{pH}$ 7.0. In case of the isolate SOB-8, sulphide oxidase production was found to be maximum $(121.33 \mathrm{U} / \mathrm{ml})$ when the initial $\mathrm{pH}$ of the medium was maintained at $\mathrm{pH}$ 9.0. Decrease in enzyme activity was observed beyond their optimum $\mathrm{pH}$.

Optimum temperature for the production of sulphide oxidase by both the strains was observed at $45^{\circ} \mathrm{C}$ (Figure 6b). The bacterial isolate, SOB-7 showed maximum sulphide oxidase activity of $125.0 \mathrm{U} / \mathrm{ml}$, where as maximum sulphide oxidase activity of $120 \mathrm{U} / \mathrm{ml}$ was observed at temperature of $45^{\circ} \mathrm{C}$ by the isolate, SOB- 8 . Sulphide oxidase productions decreased by both the bacterial isolates with increase in temperature beyond $45^{\circ} \mathrm{C}$.

Effect of nitrogen source towards sulphide oxidase synthesis was studied by amended sulphur-oxidizer medium with varying nitrogen sources (Figure 6c). The initial supplementation of culture medium with peptone showed enhanced sulphide oxidase production $(126.83 \mathrm{U} / \mathrm{ml})$ by SOB-8 and $(126.0 \mathrm{U} / \mathrm{ml})$ by SOB-7 in comparison to other source used.

Concentration of thiosulphate in sulphur-oxidizer medium was varied in a range of $5-25 \mathrm{mg} / \mathrm{ml}(\mathrm{w} / \mathrm{v})$. Sulphide oxidase production was significantly affected by the initial increased in thiosulphate concentration. Maximum sulphide oxidase productions of $125.1 \mathrm{U} / \mathrm{ml}$ by SOB- 8 and $137.32 \mathrm{U} / \mathrm{ml}$ by SOB-7 were observed when $10 \mathrm{mg} / \mathrm{ml}$ of thiosulphate was incorporated in the medium (Figure 6d).
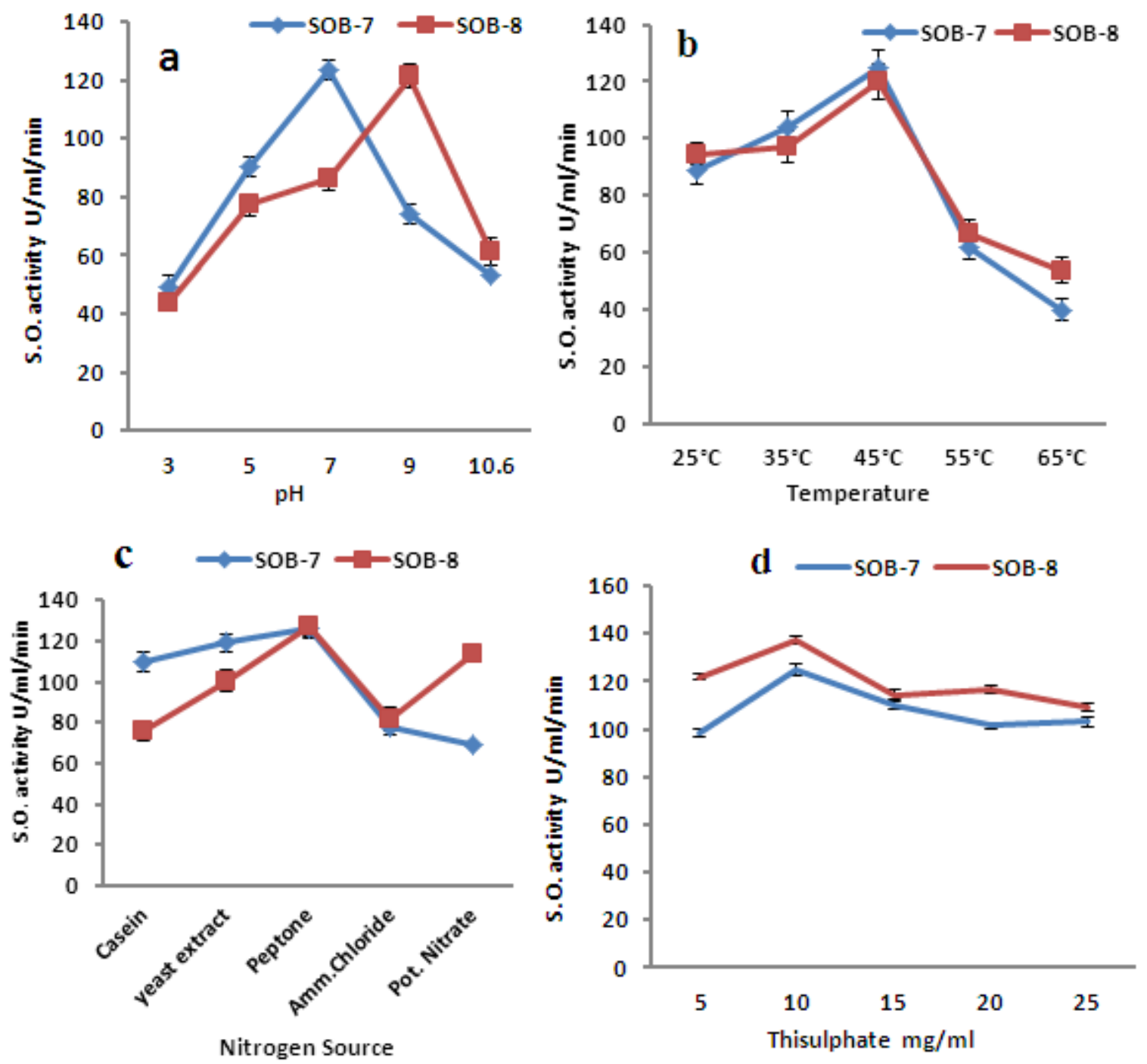

Figure 6. Effect of (a) pH, (b) Temperature, (c) Nitrogen source, (d) Thiosulphate concentration of the culture medium on sulphide oxidase production activity 
Table 1. Partial purification of sulphide oxidase from the bacterial isolates, SOB-7 and SOB-8

\begin{tabular}{|c|c|c|c|c|c|c|c|c|}
\hline Isolates & $\begin{array}{c}\text { Total Volume } \\
(\mathrm{ml})\end{array}$ & $\begin{array}{c}\text { Protein } \\
\mathrm{mg} / \mathrm{ml}\end{array}$ & $\begin{array}{c}\text { Total } \\
\text { Protein } \\
(\mathrm{mg})\end{array}$ & $\begin{array}{c}\text { Sulphide } \\
\text { oxidaseU/ml }\end{array}$ & $\begin{array}{c}\text { Total } \\
\text { Activity } \\
(\mathrm{U})\end{array}$ & $\begin{array}{c}\text { Specific } \\
\text { Activity } \\
\text { U/mg }\end{array}$ & $\begin{array}{c}\text { Fold of } \\
\text { Purification }\end{array}$ & $\begin{array}{c}\text { Total } \\
\text { Yield } \\
(\%)\end{array}$ \\
\hline $\begin{array}{c}\text { Culture extract of } \\
\text { SOB-7 }\end{array}$ & 50 & 21.7 & 1085 & $126 \pm 2.26$ & 6300 & 5.80 & 1 & 100 \\
\hline $\begin{array}{c}70 \%\left(\mathrm{NH}_{4}\right)_{2} \mathrm{SO}_{4} \\
\text { precipitation and } \\
\text { dialysis of SOB-7 }\end{array}$ & 15 & 9.2 & 138 & $154.31 \pm 2.3$ & 2314.6 & 16.77 & 2.89 & 36.74 \\
\hline $\begin{array}{c}\text { Culture extract of } \\
\text { SOB-8 }\end{array}$ & 50 & 27 & 1350 & $126.83 \pm 2.6$ & 6341.5 & 4.69 & 1 \\
\hline $\begin{array}{c}\left.70 \%(\mathrm{NH})_{2}\right)_{2} \mathrm{SO} \\
\text { precipitation and } \\
\text { dialysis of SOB-8 }\end{array}$ & 15 & 12.5 & 187.5 & $140 \pm 6.32$ & 2100 & 11.2 & 2.38 & 33.11 \\
\hline
\end{tabular}

\subsection{Partial Purification and Characterisation of Sulphide Oxidase Activity}

Partial purification of sulphide oxidase was performed by $70 \%$ of ammonium sulphate precipitation followed by dialysis and SDS-PAGE gel electrophoresis. After partial purification the enzyme of the isolate, SOB-7 showed some specific bands of approximately $72 \mathrm{kDa}, 55 \mathrm{kDa}, 50 \mathrm{kDa}$ and $43 \mathrm{kDa}$. Partially purified protein of SOB-8 revealed some specific band of approximately $30 \mathrm{KDa}$ and $25 \mathrm{kDa}$. (Figure 7a). Sulphide oxidase from the isolate, SOB-7 could be purified 2.89 fold with $36.74 \%$ yield, protein content 9.2 $\mathrm{mg} / \mathrm{ml}$ and specific activity of $16.77 \mathrm{U} / \mathrm{mg}$. Similarly sulphide oxidase from the bacterial isolate, SOB-8 was purified 2.38 fold with $33.11 \%$ yield, protein content of 12.5 $\mathrm{mg} / \mathrm{ml}$ and specific activity of $11.2 \mathrm{U} / \mathrm{mg}$ (Table 1 ).

\subsection{Characterisation of Partially Purified Sufphide Oxidase}

In the present study to determine the suitable condition for maximum enzyme activity, the reaction mixture of the partially purified enzyme was studied under different conditions of $\mathrm{pH}$, temperature and concentration of substrate.

The effect of $\mathrm{pH}$ on partially purified sulphide oxidase activity was examined by maintaining the reaction mixture at various $\mathrm{pH}$ ranging from $\mathrm{pH} 3.0$ to 10.6 in different buffer solution. The optimal $\mathrm{pH}$ for maximum sulphide oxidase activity by the isolate, SOB-7 was found at $\mathrm{pH} 7.0$ (136.66 $\mathrm{U} / \mathrm{ml}$ ), whereas $\mathrm{pH} 9.0$ was found to be optimum for maximum sulphide oxidase activity $(131.88 \mathrm{U} / \mathrm{ml})$ by the isolate, SOB-8 (Figure 7b).

The effects of temperature on partially purified sulphide oxidase activity of both the isolates were examined at various temperatures ranging from $25^{\circ} \mathrm{C}$ to $65^{\circ} \mathrm{C}$. Optimal temperature for partially purified sulphide oxidase activity of both the isolate was found to be $45^{\circ} \mathrm{C}$, beyond which steady decrease in enzyme activity was observed (Figure 7c). The maximum sulphide oxidase activity by the bacterial isolate, SOB-7 was found to be $145.0 \mathrm{U} / \mathrm{ml}$, where as SOB-8 showed maximum enzyme activity of $140.0 \mathrm{U} / \mathrm{ml}$ at $45^{\circ} \mathrm{C}$.

Substrate specificity of the purified enzyme was performed by assaying the activity of the purified enzyme against different concentrations of $\mathrm{Na}_{2} \mathrm{~S}$ solution (0.25-2.5 $\mathrm{mg} / \mathrm{ml}$ ) to the reaction mixture. The enzyme activities of both the isolates increased up to a certain substrate concentration and remain almost same thereafter. It was observed that the partially purified enzyme of both the isolate, SOB-7 $(154.31 \mathrm{U} / \mathrm{ml})$ and SOB-8 $(137.89 \mathrm{U} / \mathrm{ml})$ showed higher activity at $1.5 \mathrm{mg} / \mathrm{ml}$ of substrate concentration and remained almost same thereafter (Figure $7 d)$. 

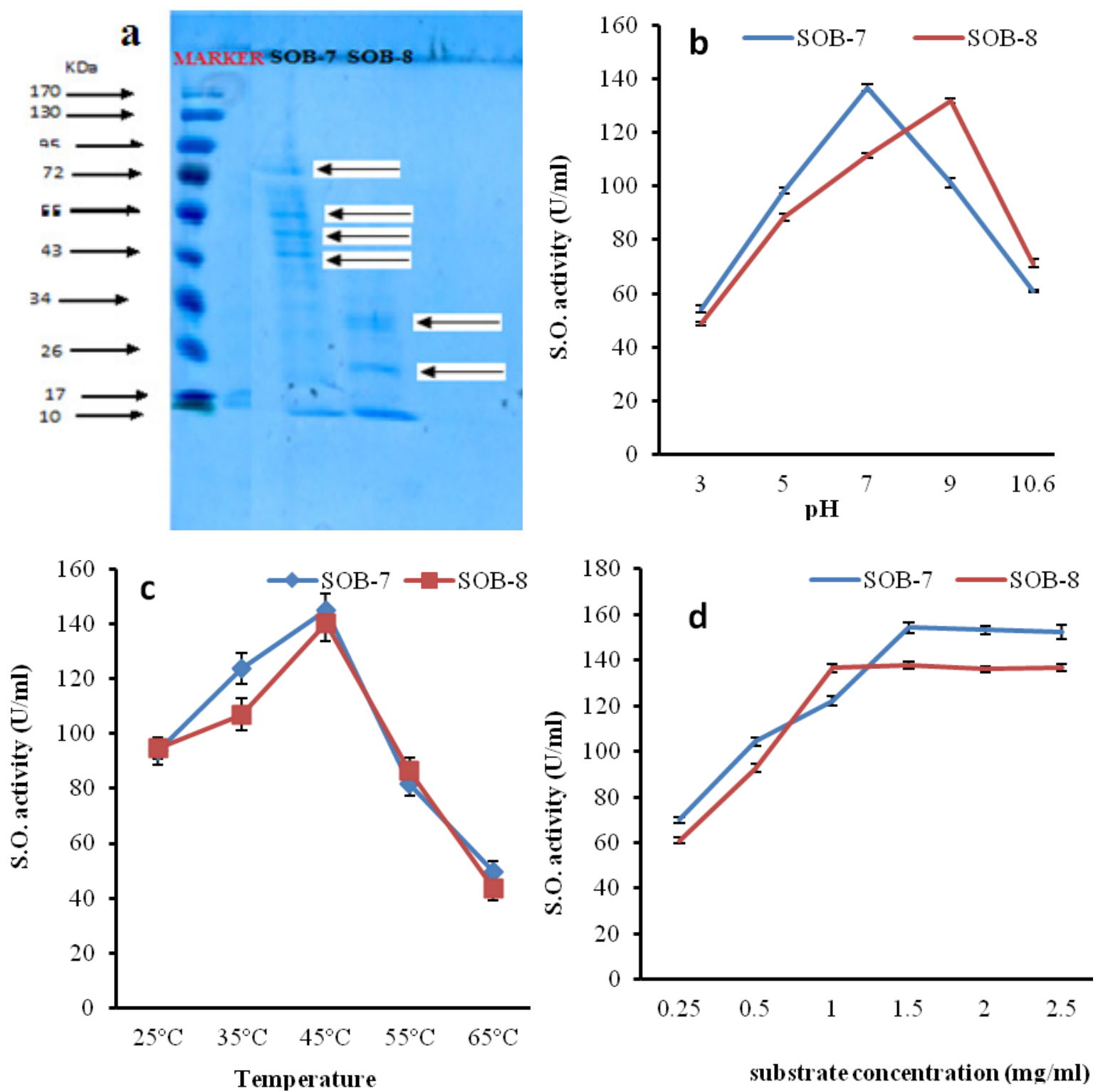

Figure 7. (a) SDS-PAGE of partially purified sulphur oxidase from SOB-7 and SOB-8, effect of (b) pH, (c) temperature, (d) substrate concentration on partially purified sulphide oxidase activity.

\section{Discussion}

Two sulphur oxidising bacterial isolates (SOB-7 and SOB-8) were isolated from mangrove soil of Mahanadi delta, based on their $\mathrm{pH}$ reduction abilities where the blue color is faded to color less due to reduction of $\mathrm{pH}$. Studies on isolation of sulphur oxidizing bacteria by various researchers reveal their existence in mud soil, canal water, fresh water sources [24] and also from various mangrove ecosystems [14]. Purple sulphur bacteria, a phototrophic anaerobe requires sulphide which they oxidise to sulphate for their growth are widely distributed in sulphide rich reducing environment such as mangrove, mud flat and polluted water [25]. Thatoi et al. [26] reported the occurance of Pseudomonas sp. that oxidises sulphur in the mangrove of Bhitarakanika, Odisha. Sulphur oxidising bacteria was also reported from garden soil, activated sludge [27] and soil sulphur compost [28]. Heterotrophic isolates of thiosulphate producing bacteria, which acidified the medium moderately by 0.5 to $1.0 \mathrm{pH}$ units, were obtained from marine sediments and hydrothermal vents [29].

In the present study, $\mathrm{pH}$ reduction of the medium was due to the generation of acid in the medium. Reduction in $\mathrm{pH}$ of the growth medium by sulphur oxidizing bacteria was reported earlier by Donati et al. [30].

In the present study, to screen out the potential sulphur oxidising bacteria, medium was amended with sodium thiosulphate and the sulphate ion production ability of both the isolates was measured. The isolates, SOB-7 and SOB-8 were found to produce maximum sulphate ion i.e. $245 \mathrm{mg} / \mathrm{ml}$ and $240 \mathrm{mg} / \mathrm{ml}$ respectively after $216 \mathrm{~h}$ of incubation. Ravichandra et al. [31] reported the maximum sulfate ion production of $14-40 \mathrm{mg} / \mathrm{ml}$ by a Thiobacillus $\mathrm{sp}$. 
Further optimisations of sulphide oxidase production by these two strains were carried out. Among these two isolates, SOB-8 showed comparatively highest sulphide oxidase production ability $(126.83 \mathrm{U} / \mathrm{ml})$ after $216 \mathrm{~h}$ of incubation followed by the isolate, SOB-7 $(126 \mathrm{U} / \mathrm{ml})$ at $240 \mathrm{~h}$ of incubation. Our finding is comparable to the findings of others. Crude extract of thiosulphate oxidase from $P$. aeruginosa showed maximum activity of $130 \mathrm{U} / \mathrm{ml}$, reported by Schook and Berk [32]. Rohwerdert and Sand [33] reported sulphur dioxygenase activity of $5.0 \pm 1.7 \mathrm{nmol}$ min-1 by Acidithiobacillus and Acidiphilium sp.

On the basis of their morphological, physiological, biochemical test and $16 \mathrm{~S}$ rRNA sequencing, both the isolates were identified as Klebsiella sp. (SOB-7) and Micrococcus sp. (SOB-8). Sulphur oxidising activity of Micrococcus sp. were well reported earlier from Indian Terai soil- a Himalayan foot hill soil of the order mollisol [34].

The rate of growth and metabolism of bacteria depend very much on the composition of the medium and the prevalent environmental conditions. Various bacterial strains differ in their nutritional requirements and cultural conditions for optimal growth and enzyme production. In the present study, an attempt has been made to optimize the production of sulphide-oxidizing enzyme from these two bacterial isolates of Mahanadi delta by manipulating the physical and environmental factors such as $\mathrm{pH}$, temperature, inoculums size, thiosulphate concentration and different nitrogen sources.

The bacterial isolate SOB-7 showed maximum sulphide oxidase activity $(123.66 \mathrm{U} / \mathrm{ml})$ at $\mathrm{pH} 7.0$. whereas the isolate, SOB-8 showed maximum sulphide oxidase activity $(121.33 \mathrm{U} / \mathrm{ml})$ at $\mathrm{pH}$ 9.0. The optimum $\mathrm{pH}$ for sulphur-oxidizing bacteria was varied depending on the microbial habitat. The halo alkaliphilic Thioalkalivibrio isolated from soda lakes showed optimum sulphide oxidase at $\mathrm{pH} 10.0$ [35] while Thiobacillus caldus found in environment such as coal spoil heaps was able to grow down to $\mathrm{pH} 1.0$ [36]. However, Mohapatra et al. [6] had reported in their work that the optimum $\mathrm{pH}$ for sulphide oxidase production by Arthrobacter sp. strain FR-3 in GY medium was at $\mathrm{pH}$ 7.5.

Temperature is one of the most important environmental factors affecting growth and activity of microorganisms [37]. Optimum temperature for sulphide-oxidase production by both the strain was found to be $45{ }^{\circ} \mathrm{C}$ and it starts to decrease steadily beyond that temperature. This might be due to denaturation of enzyme that leads to changes in the configuration of enzyme active site and loss of catalytic properties [38]. Hence both the isolates SOB-7 and SOB-8 were found to be mesophilic in nature and most of the proteins from mesophiles are inactivated at temperatures above $45^{\circ} \mathrm{C}$ [38].

Nitrogen is a major element in proteins, nucleic acid and several other constituents in the cell. Nitrogen can be found in nature as both organic and inorganic forms. In the present study peptone was found to be the best nitrogen sources for sulphide oxidase production. Asgher et al. [39] stated that organic sources like yeast extract and peptone usually have stimulating effect on enzyme activity. The result of this study is in good agreement with Asgher et al. [39] where stimulation of sulphide oxidase activity can be seen when peptone and yeast extract was supplied in the medium. Most enzymes including amylase, protease and nitrate reductase are repressed by ammonium salts [40-41]. In this study, ammonium salts also showed an inhibitory effect towards sulphide oxidase production considerably. In the present study when fermentation was carried out with ammonium chloride as a nitrogen source it yields very low sulphide oxidase production by both the isolates. Mohapatra et al. [6] also observed that ammonium salts repressed the production of sulphide oxidase by the Arthrobacter sp.

It should be noted that activity of sulphide oxidase enzymes involved in the metabolism of inorganic sulphur compounds varied depending on type of sulphur compounds added to the medium. In the present study, sulphide oxidase activity significantly affected by the increased in thiosulphate concentration from $05-10 \mathrm{mg} / \mathrm{ml}$ $(w / v)$ of the medium and gradually declined thereafter. This may be due to the inhibition of thiosulphate utilization at high concentration which leads to less consumption of thiosulphate by both the bacteria. According to Spring et al. [42], concentration of thiosulphate above the optimum concentration inhibits the bacterial growth and thiosulphate utilization by the bacteria. According to Eccleston and Kelly [43], very low thiosulphate concentration allowed very high oxidation rate. Higher thiosulphate concentration only resulted in loss of thiosulphate oxidizing capacity and decrease in cell mass production. This might be due to the thiosulphate toxicity at high concentration that can repressed cell growth and also thiosulphate oxidizing capability of the bacteria [44]. Skirnisdottir et al. [45] observed that the conversion of thiosulphate to sulphate by Hydrogenobacter sp. was reduced with the increase thiosulphate concentration. The above description also affirms the present finding that high concentration of thiosulphate was not suitable for the production of sulphide oxidase by both strains.

A number of sulphide oxidases have been purified from autotrophs, and their oxidation mechanisms have been investigated. For instance, the purified sulphide oxidoreductase from Thiobacillus ferrooxidans [46-47] performs an important role in energy production, and Chlorobium thiosulphatophilum [48] has a cytochrome c-553, that plays a sulphide oxidization role in electron transport. However no such reports on sulphide oxidases have been published on microorganism from mangrove environment. So, this is the first attempt made to partially purify and characterise sulphide oxidase from microorganism from mangrove soil of Mahanadi river delta, Odisha, Indi. The partially purified sulphide oxidase of SOB-7 in SDS-PAGE exhibits four consecutive bands where as the bacterial isolate, SOB- 8 exhibits two consecutive bands. According to Mohapatra et al. [6], the purified sulphide oxidase was showed to be monomer with a molecular weight of $43 \mathrm{kDa}$. This molecular weight was 
found to be higher compared to the purified sulphide oxidase from the Bacillus sp. BN53-1 which is $37 \mathrm{kDa}$ [49]. Further the partially purified enzymes were characterised in different $\mathrm{pH}$, temperature and $\mathrm{Na}_{2} \mathrm{~S}$ concentration.

To maintain the hydrogen ion concentration or $\mathrm{pH}$ of an enzyme is most important because a change in $\mathrm{pH}$ can change the charge properties of the substrate so that it affects the catalysis of the E+S complex. From the observation it was found that in case of the isolate SOB-7, optimum $\mathrm{pH}$ for sulphide oxidase activity is 7.0 after which it showed decreasing in binding with the substrate hence decrease in activity. Similarly the maximum sulphide oxidase activity of the isolate SOB-8 was observed at pH-9.0. Nakada and Ohta [49] reported optimum activity of the purified sulphide oxidase at at $\mathrm{pH}-8.0$.

Temperature plays a major rule in activation of the enzyme to bind the substrate. Beyond the optimum temperature the protein structure denaturised resulting the thermal deactivation or deceleration in enzyme kinetics. The optimum enzyme activities of different enzyme system such as amylase, protease, sulphide oxidase, phosphatase, sulphide oxidase etc. are dependent to the organism and the habitat from where they are isolated. In the present study sulphur oxidising bacteria were isolated from a tropical mangrove forest hence most of the microbes are mesophillic. Both the bacterial isolates showed optimum activity at $45^{\circ} \mathrm{C}$ which was also observed after partial purification. Nakada and Ohta [49] reported optimum activity of the purified sulphide oxidase at $40^{\circ} \mathrm{C}$.

In the present investigation the ranges of different concentrations of $\mathrm{Na}_{2} \mathrm{~S}$ solution were added to the reaction mixture $(0.25-2.5 \mathrm{mg} / \mathrm{ml})$ and observed that both the isolates SOB-7 and SOB-8 showed increased activity from 0.25 to $1.5 \mathrm{mg} / \mathrm{ml}$ of $\mathrm{Na}_{2} \mathrm{~S}$, after which it showed saturated activity with the enzyme. Hence the rate of formation of product depends on the activity of the enzyme itself, and adding more substrate will not affect the rate of the reaction to any significant effect.

\section{Conclusions}

The present study emphasizes isolation and identification of two efficient sulphur oxidizing bacteria such as Klebsiella sp., and Micrococcus sp. from mangrove soil of Mahanadi river delta, Odisha India. Both the bacterial isolates could efficiently oxidise the reduced sulphur compound by decreasing the $\mathrm{pH}$ of the culture medium and efficiently produced sulphate ion. Sulphide oxidase activity of both the isolates were optimized and characterized after partial purification which could probably help taxonomists, agriculturalists and even some industrialists in their own researches. Use of these bacteria as bio-inoculants may enhance sulphur oxidation in soil and increase soil available sulphate to minimize the S-fertilizer application. They may have also probable use to reduce environmental pollution and promotes sustainable agriculture.

\section{REFERENCES}

[1] R.Vidyalakshmi, R. Sridar. Isolation and characterization of sulphur oxidizing bacteria. Journal of Culture Collection, vol. 5, 73-77, 2007.

[2] M.T. Madigan, J.M. Martinko, J. Parker. Brock Biology of Microorganism. 9th ed. Upper Saddle River, NJ: Prentice-Hall, 2000.

[3] J. L. Katyal, K. L. Sharma, K, Srinivas. ISI/FAI/IFA Symposium on sulphur in balanced fertilization. New Delhi, India, Proceedings, vol. 2, 1-11, 1997.

[4] C.G. Friedrich, F. Bardischewsky, D. Rother. Prokaryotic sulfur oxidation. Current Opinion in Microbiology, vol. 8, 253-259, 2005.

[5] M. Wainwright. Sulphur oxidation in soils. Advances in Agronomy, vol. 37, 350-392, 1984.

[6] B.R. Mohapatra W. D. Gould, O. Dinardo, S. Papavinasam, R. W. Revie. Optimization of culture conditions and properties of immobilized sulfide oxidase from Arthrobacter species. Journal of Biotechnology, vol. 124, 523-531, 2006.

[7] Y. Nakada, Y. Ohta. Hydrogen sulfide removal by a deodorant bacterium Bacillus sp. BN53-1. Seibutsu Kogaku Kaishi, vol.75, 425-431, 1997.

[8] G. Holguin, P.G. Zamorano, L.E. De-Bashan, R. Mendoza, E. Amador, Y. Bashan. Mangrove health in an arid environment encroached by urban development - a case study. Science of the Total Environment, vol. 363, 260-274, 2006.

[9] H.W. Zhou, C.L. Guo, Y.S. Wong, N.F.Y. Tam. Genetic diversity of dioxygenase genes in polycyclic aromatic hydrocarbon-degrading bacteria isolated from mangrove sediments. FEMS Microbiology Letter, vol. 262, 148-157, 2006.

[10] D.M. Alongi. Vertical profiles of bacterial abundance, productivity and growth rates in coastal sediments of the central Great Barrier Reef lagoon. Marine Biology, vol. 112, 657-663, 1992.

[11] A. Rojas, G. Holguin, B.R. Glick, Y. Bashan. Syn-ergism between Phyllobacterium sp. (N2-Fixer) and Bacillus licheniformis (P-Solubilizer), both from a semiarid mangrove rhizosphere. FEMS Microbiology Ecology, vol. 35, 181-187, 2001.

[12] M. Holmer, P. Storkholm. Sulphate reduction and sulphur cycling in lake sediments: a review. Freshwater Biology, vol. 46, 431-451, 2001.

[13] E.G. Ruby, C.O. Wirsen, H.W. Jannasch. Chemolithotrophic sulfur-oxidizing bacteria from the Galapagos rift hydrothermal vents. Applied and Environmental Microbiology, vol. 42, 317-324, 1981.

[14] M.Varon-Lopez, A.C.F. Dias, C.C. Fasanella, A. Durrer, I.S. Melo, E. E. Kuramae, F. D. Andreote. Sulphur-oxidizing and sulphate-reducing communities in Brazilian mangrove sediments. Environmental Microbiology, vol. 16, 845 -855, 2014. 
[15] J.M.Visser, G.A.H. de Jong, L.A. Robertson, J.G. Kuenen. A novel membrane-bound flavocytochrome c sulfide dehydrogenase from the colorless sulfur bacterium Thiobacillus sp. W5. Achieves of Microbiology, vol. 167, 295-301, 1997.

[16] M.W. Beijerinck. Phenomenes de reduction produits par les microbes (Conference avec demonstrations faite - Delft, le 16 avril 1903). Archs Neerrl Science Series, vol. 29, 131-157, 1904.

[17] R.E. Buchanan, N.E. Gibbons. Bergey's manual of determinative bacteriology. (8th edn), The Williams and Wilkins Co., Baltimore, 747-842, 1974.

[18] S. Das, J. Mishra, S.K. Das, S. Pandey, D.S. Rao, A. Chakraborty, M. Sudarshan, N. Das, H.N. Thatoi. Investigation on mechanism of $\mathrm{Cr}(\mathrm{VI})$ reduction and removal by Bacillus amyloliquefaciens, a novel chromate tolerant bacterium isolated from chromite mine soil. Chemosphere, vol. 96, 112-121, 2014.

[19] J.M. Cha, W.S. Cha, J.H. Lee. Removal of organosulphur odour compound by Thiobacillus novellas SRM, Sulphur oxidising microorganism. Process Biochemistry, vol. 34, 659-665, 1999.

[20] A. Kolmert, P. Wikström, K.B. Hallberg. A Fast and Simple Turbidimetric Method for the Determination of Sulfate in Sulfate-Reducing Bacterial Cultures. Journal of Microbiological Methods, vol. 41, 179-184, 2000.

[21] T. Hirano, H. Kurosawa, K. Nakamura, Y. Amano. Simultaneous removal of hydrogen sulphide and trimethylamine by a bacterial deodorant. Journal of Fermentation and Bioengineering, vol. 81, 337-342, 1996.

[22] U. K. Laemmli. Cleavage of structural proteins during the assembly of the head of bacteriophage T4. Nature, vol. 227, 680-685, 1970.

[23] Lowry, N.J. Rosebrough, A.L. Farr, R.J. Randall. Protein Measurement with the Folin Phenol Reagent. Journal of Biological Chemistry, vol. 193, 265-275, 1951.

[24] D.P. Kelly, A.P. Harrison. Genus Thiobacillus Beijerinck. In: Bergey's manual of Systamatic Bacteriology, G. T. Staley, N Pfenning, J. G. Holt (Eds.), Baltimore: Williams \&Wilkinson Co, 1842-1871, 1988.

[25] N. Pfenning. Phototrophic green and purple bacteria. A comparative, systematic survey. Annual Review in Microbiology, vol. 31, 275-290, 1977.

[26] H.N.Thatoi, B.C. Behera, T.K. Dangar, R.R. Mishra. Microbial biodiversity in mangrove soil of Bhitarakanika, Odisha, India. International Journal of Environmental Biology, vol. 2, No.2, 50-58, 2012.

[27] C.V.R. Ayyar, T.S.S. Perumal, R.V. Norris. The oxidation of sulphur in suspensions of activated sludge and its influence on the solubilization of mineral phosphate. Journal of Indian institute of Science, vol. 11, 85-90, 1929.

[28] H.D. Brown. Sulfofication in pure and wined cultures with special reference to sulphate production, hydrogen ion-concentration and nitrification. Journal of American Society of Agronomy, vol. 15, 350-382, 1923.

[29] J.L. Katyal, K.L. Sharma, K. Srinivas ISI/FAI/IFA Symposium on sulphur in balancedfertilization. New Delhi,
India, 1997.

[30] E. Donati, G. Curutchet, C. Pogliani, P. Tedesco. Bioleaching of covellite using pure and mixed cultures of Thiobacillus ferrooxidans and Thiobacillus thiooxidans. Process Biochemistry, vol. 31, 129-134, 1996.

[31] P. Ravichandra, G. Mugeraya, A. Ganganirao, M. Ramakrishna, A. Jetty. Isolation of Thiobacillus sp from aerobic sludge of distillery and dairy effluent treatment plants and its sulfide oxidation activity at different concentrations. Journal of Environmental Biology, vol. 28, No. 4, 819-823, 2007.

[32] L.B. Schook, R.S. Berk. Nutritional studies with Pseudomonas aeruginosa grown on inorganic sulfur sources. Journal of Bacteriology, vol. 133, 1377-1382, 1979.

[33] R. Rohwerdert, W. Sand. The sulfane sulfur of persulfides is the actual substrate of the sulfur-oxidizing enzymes from Acidithiobacillus and Acidiphilium sp. Microbiology, vol. 149, 1699-1709, 2003.

[34] N. Chattopadhyaya, B.K. Dey. Chemoheterotrophic sulphur oxidising microorganisms of a Terai soil I. Oxidation of inorganic and organic sulphur by microorganisms, isolated in sucrose- sodiumthiosulphate agar. Zentralblatt fur Mikrobiologie, vol. 148, No. 7, 517-522, 1993.

[35] D.Y. Sorokin, T.P. Tourova, A.M. Lysenko, L.L. Mi- tyushina, J.G. Kuenen. Thioalkalivibrio thiocyanoxi-dans sp. nov. and Thioalkalivibrio paradoxus sp. nov., Novel Alkaliphilic, Obligately Autotrophic, Sulfur-Oxi- dizing Bacteria Capable of Growth on Thiocyanate, from Soda Lakes. International Journal of Systematic and Evolutionary Microbiology, vol. 52, 657-664, 2002

[36] D.Y. Sorokin, T.P. Tourova, A.N. Antipov, G. Muyzer, J.G. Kuenen. Anaerobic Growth of the Haloalka- liphilic Denitrifying Sulfur-oxidizing Bacterium Thialka- livibrio thiocyanodenitrificans sp. nov. with Thiocy- anate. Microbiology, vol. 150, 2435, 2004.

[37] N.S. Ashaari, M.M. Salleh, R.M. Illias. Degradation of thiosulfate by sulfide oxidizing enzyme produced by bacteria locally isolated from effective microorganism active solution (EMAS). Petroleum and natural resources process. Regional Postgraduate Conference on Engineering and Science, Johore, 2006.

[38] T. Sugio, C. Domatsu, O. Munakata, T. Tano, K. Imai. Role of Ferric Ion-Reducing System in Sulfur Oxidation of Thiobacillus ferrooxidans. Applied and Environmental Microbiology, vol. 49, No. 6, 1401-1406, 1985.

[39] M. Asgher, M.J. Asad, S.U. Rahman, R.L. Legge. A thermostable $\alpha$-amylase from a moderately thermophilic Bacillus subtilis strain for starch processing. Journal of Food Engineering, vol. 79, 950-955, 2007.

[40] S. Sanchez, A.L. Demain. Metabolic Regulation of Fermentation Processes. Enzyme \& Microbial Technology, vol. 31, No. 7, 895-906, 2002.

[41] R.K. Saxena, K. Dutt, L. Agarwal, P. Nayyar. Highly thermostable and alkaline amylase from a Bacillus sp. PN5. Bioresource Technology, vol. 98, 260-265, 2007.

[42] S. Spring, P. Kämpfer, K.H. Schleifer. Limnobacter thiooxidans gen. nov., sp. nov., a Novel Thiosulfate Oxidizing Bacterium Isolated from Freshwater Lake 
Sediment. International Journal of Systematic and Evolutionary. Microbiology, vol. 51, 1463-1470, 2001.

[43] M. Eccleston, D.P. Kelly. Oxidation kinetics and chemostat growth kinetics of Thiobacillus ferrooxidans on tetrathionate and thiosulfate. Journal of Bacteriology, vol. 134, No. 3, 718-727, 1978.

[44] P.J.F. Gommers, J.G. Kuenen. Thiobacillus strain Q, a chemolithoheterotrophic sulphur bacterium. Achieves of Microbiology, vol. 150, 117-125, 1988.

[45] S. Skirnisdottir, G.O. Hreggvidson, O. Holst, J.K. Kristjansson. Isolation and Characterization of a Mixotrophic Sulfur-Oxidizing Thermus scotoductus. Extremophile, vol. 5, 45-51, 2001.
[46] Sugio T. Noguchi M. Tano T. Detoxification of sulphite produced during the oxidation of elemental sulphur by Thiobacillus ferrooxidans. Agricultural and Biological Chemistry, vol. 51, 1431-1433, 1987.

[47] T. Sugio, Y. Tsujita, K. Inagaki, T. Tano. Reduction of cupric ions with elemental sulphur by Thiobacillus ferrooxi-dans. Applied and Environmental Microbiology, vol. 56, 693-696, 1990.

[48] A. Kusai, T.Yamanaka. Cytochrome-c 553, Chlorobium thiosulfatophilum, is a sulfide cytochrome c reductase. FEBS Letter, vol. 34: 235-237, 1973a.

[49] Y. Nakada, Y. Ohta. Purification and properties of hydrogen sulfide oxidase from Bacillus sp. BN53-1. Journal of Bioscience and Bioengineering, vol. 87, No. 4, 452-455, 1999. 